\title{
"Base Genep" Instant Spices Quality For Sale in East Denpasar
}

\author{
Sofia Nggoweng ${ }^{1}$, Ni Made Ayu Suardani Singapurwa ${ }^{2}$, I Nyoman Rudianta ${ }^{3}$.
}

\author{
Department of Food Science and Technology, Faculty of Agriculture, Warmadewa University, Indonesia. \\ ${ }^{1}$ E-mail: sofianggoweng@mail.com \\ ${ }^{2}$ E-mail: a.suardani@ymail.com \\ ${ }^{3}$ E-mail: nyomanrudianta@ymail.com
}

\begin{abstract}
Instant spices is a mixture of several spices that are young to be found in the market at an affordable price, and are usually used immediately as a cooking spice for certain foods. This study aims to determine the quality of the "Base Genep" instant spices sold in the East Denpasar Market. This research is a descriptive study using survey and experimental methods in the laboratory. The number of samples to be studied was 44 samples from 81 populations. The variables in the study were moisture content, $p H$, Escherichia coli, Total Plate Count (TPC), and mold. The results showed that from 44 samples of "Basa Genep" instant seasoning water content test results obtained were $21.62 \%$ - 23.707\%, while the $\mathrm{pH}$ value of 44 samples of "Basa Genep" instant spice was obtained between 2.2-2.5 so that it meets the requirements.
\end{abstract}

Keyword: Base Genep, spices sold, Balinese foods

\section{Introduction}

Indonesia is one of the countries rich in spices. The diversity of spices that exist has been widely used by people from various regions in Indonesia to obtain certain properties and characteristics of the product they want to produce. There are quite a few traditional Indonesian foods that use spices as ingredients to add more delicious food flavors. Various types of spices that are typical in Indonesia, for example, Rawon spices (typical Surabaya), rendang spices (typical of Padang), Opor spices (typical of Central Java), and many other spices, one of which is the Balinese "Basa Genep " spice.

Modern Balinese society demands to carry out all its activities effectively and efficiently. This is reflected in their lifestyle, such as how to choose a domicile, how to communicate, transportation, and also in the consumption pattern of many people who still use ready-to-eat food and beverage products, as well as semi-processed food. One product that is very easy to get is the wet "Basa genep" instant seasoning. This instant spice is very practically used by Balinese people in general. Because most Balinese foods such as Babi guling, Ayam betutu, Lawar are generally complicated and cannot be served quickly, one way to serve them quickly and easily is to use ready-to-use seasonings, namely instant Basa Genep spices in wet form. But in reality, there are still many. The purpose of this research was to determine the quality of instant kitchen spices "Base Genep" sold in the East Denpasar Market.

\section{Material and Methods}

\subsection{Place and Time of Research}

This research was conducted at the Laboratory of the Faculty of Agriculture, Warmadewa University, and Denpasar Veterinary Center. 


\subsection{Research Materials}

Easy Test Kit, Merckoquant Kit, Durham tube, Petri dish, test tube, $1 \mathrm{ml}, 2 \mathrm{ml}, 5 \mathrm{ml}, 10 \mathrm{ml}$ pipette, media bottle, scissors, tweezers, inoculation needle (ose), stomacher, bunsen burner, $\mathrm{pH}$ meter, scale, magnetic stirrer, tube shaker (vortex), incubator, water bath, autoclave, sterile cabinet (clean bench), refrigerator, freezer, volumetric pipette, colony counter, inoculation needle (ose).

Spices Traditional "Base Genep" seasoning taken from the market circulating in East Denpasar. Aquades, BPW (Buffered Pepton Water), PCA (Plate Count Agar).

\subsection{Research Design}

This type of research is a descriptive study, this research uses survey and experimental methods in the laboratory. The population in the study was obtained by a survey using a census, namely the number of traders of traditional instant spices "Base Genep" in the market of East Denpasar sub-district as many as 81 traders. Based on the Slovin formula, namely the determination of the minimum number of samples to be studied with a set margin of error of $10 \%$ (95\% confidence level), the calculation is as follows:

$$
\frac{\mathbf{N}}{\left(1+\left(N X e^{2}\right)\right)}
$$

Where $\mathrm{n}$ is the sample, $\mathrm{N}$ is the population and "e" is the margin of error $(10 \%)$. With the Slovin formula, the minimum number of samples to be studied is 44 samples from 81 existing populations.

\subsection{Research implementation}

This research stage consisted of sampling, identification of total mold, identification of Escherichia coli, identification of total plate count (TPC), water content, $\mathrm{pH}$ test, and data analysis.

\subsection{Data Analysis}

Based on the results of the research data obtained, a descriptive analysis will be carried out. The descriptive analysis carried out will refer to microbiological contamination for seasoning testing (wet) according to BPOM RI Regulation No: 16 of 2016. From the results of this analysis, it will be known the contaminants contained in traditional spices found in the East Denpasar market, while for the analysis of content data Water and $\mathrm{pH}$ were analyzed using descriptive statistics

\section{Results and Discussion}

\subsection{Total Plate Count}

The results of the Total Plate Count (TPC) test on 44 samples of "Basa Genep" instant seasoning obtained from 7 traditional markets in East Denpasar District all meet the requirements of BPOM RI Regulation No: 16 of 2016, namely the maximum limit of Total Plate Count (TPC) contamination in spices. instant alkaline $1 \times 10^{4}$ Colonies/gram. The antimicrobials of spices are compounds such as phenols, flavonoids, katerpenoids acetoksicavikol, acetates, and other essential oils. These compounds can suppress microbial growth because they can act as enzyme coagulators so that cell wall formation is inhibited. The results of the Total Plate Count (TPC) test can be seen in Table 1. 
Table 1

Total Plate Count (TPC) Test Results on "Basa Seasoning Samples."

Genep "which is circulating in the Traditional market of Denpasar District

\begin{tabular}{|c|c|c|c|c|}
\hline No & Market Name & $\begin{array}{c}\text { Code } \\
\text { Sample }\end{array}$ & $\begin{array}{c}\text { Result Testing } \\
\text { (Colonies / g) }\end{array}$ & Information \\
\hline 1. & Yadnya Market & PS1 & $5 \times 101$ & MS \\
\hline 2. & Yadnya Market & PS2 & $2 \times 101$ & MS \\
\hline 3. & Yadnya Market & PS3 & $4 \times 101$ & MS \\
\hline 4. & Yadnya Market & PS4 & $5 \times 101$ & MS \\
\hline 5. & Yadnya Market & PS5 & $8 \times 101$ & MS \\
\hline 6. & Yadnya Market & PS6 & $1.1 \times 102$ & MS \\
\hline 7. & Yadnya Market & PS7 & $7 \times 101$ & MS \\
\hline 8. & Tamba Market & PS8 & $1.1 \times 102$ & MS \\
\hline 9. & Tamba Market & PS9 & $8 \times 101$ & MS \\
\hline 10. & Tamba Market & PS10 & $7.5 \times 101$ & MS \\
\hline 11. & Tamba Market & PS11 & $6 \times 101$ & MS \\
\hline 12. & Tamba Market & PS12 & $2 \times 101$ & MS \\
\hline 13. & Gunung Sari Market & PS13 & $3.0 \times 101$ & MS \\
\hline 14. & Gunung Sari Market & PS14 & $4.1 \times 102$ & MS \\
\hline 15. & Gunung Sari Market & PS15 & $5.1 \times 102$ & MS \\
\hline 16. & Gunung Sari Market & PS16 & $5.4 \times 102$ & MS \\
\hline 17. & Gunung Sari Market & PS17 & $4.0 \times 101$ & MS \\
\hline 18. & Gunung Sari Market & PS18 & $4.4 \times 102$ & MS \\
\hline 19. & Gunung Sari Market & PS19 & $4.0 \times 101$ & MS \\
\hline 20. & Kerta Sari Market & PS20 & $1.1 \times 102$ & MS \\
\hline 21. & Kerta Sari Market & PS21 & $1.1 \times 102$ & MS \\
\hline 22. & Kerta Sari Market & PS22 & $7.0 \times 101$ & MS \\
\hline 23 & Kerta Sari Market & PS23 & $1.6 \times 102$ & MS \\
\hline 24. & Kerta Sari Market & PS24 & $8.0 \times 101$ & MS \\
\hline 25. & Kerta Sari Market & PS25 & $6.0 \times 101$ & MS \\
\hline 26. & Kerta Sari Market & PS26 & $1.7 \times 102$ & MS \\
\hline 27. & Kerta Sari Market & PS27 & $2.3 \times 102$ & MS \\
\hline 28. & Kerta Sari Market & PS28 & $1.3 \times 102$ & MS \\
\hline 29. & Waringin Sari Market & PS29 & $1.1 \times 102$ & MS \\
\hline 30. & Waringin Sari Market & PS30 & $7.0 \times 101$ & MS \\
\hline 31. & Waringin Sari Market & PS31 & $1.2 \times 102$ & MS \\
\hline 32. & Waringin Sari Market & PS32 & $1.5 \times 102$ & MS \\
\hline 33. & Pakraman trainer market & PS33 & $1.2 \times 102$ & MS \\
\hline 34. & Pakraman trainer market & PS34 & $9.0 \times 101$ & MS \\
\hline 35. & Pakraman Penatih market & PS35 & $2.0 \times 102$ & MS \\
\hline 36. & Pakraman Penatih market & PS36 & $1.6 \times 102$ & MS \\
\hline 37. & Pakraman Penatih market & PS37 & $1.0 \times 102$ & MS \\
\hline 38. & Pakraman Penatih market & PS38 & $2.2 \times 102$ & MS \\
\hline 39. & Pakraman Penatih market & PS39 & $2.2 \times 102$ & MS \\
\hline 40. & PasarTanjung Bungkak & PS40 & $2.3 \times 102$ & MS \\
\hline 41. & Tanjung Bungkak Market & PS41 & $1.8 \times 102$ & MS \\
\hline 42. & Tanjung Bungkak Market & PS42 & $1.3 \times 102$ & MS \\
\hline 43. & Tanjung Bungkak Market & PS43 & $1.1 \times 102$ & MS \\
\hline 44. & Tanjung Bungkak Market & PS44 & $1.4 \times 102$ & MS \\
\hline
\end{tabular}

MS: Qualified

\subsection{Escherichia coli}

The results of Escherichia coli testing on 44 samples of "Basa Genep" instant seasoning obtained from 7 traditional markets in East Denpasar District all meet the requirements of BPOM RI Regulation No: 16 of 2016 based on ISO 4833-1-2013. That is the maximum limit of Escherichia coli contamination in wet instant seasoning $<3.6$ / gram. Escherichia coli is a group of coliform bacteria which has the property to grow at a temperature of $10-40^{\circ} \mathrm{C}$, with an optimal temperature of $37^{\circ} \mathrm{C}$ [1]. Escherichia coli is relatively very sensitive to heat and can be activated at the pasteurization temperature of the food or during food cooking [2].

The content of secondary metabolite compounds in ginger, especially the flavonoids, phenols, terpenoids, and essential oils [3]. These secondary metabolite compounds produced by the Zingiberaceae plant can generally inhibit the growth of pathogenic bacteria that are detrimental to 
human life, including Escherichia coli, Bacillus subtilis, Staphylococcus aureus, Neurospora sp, Rhizopus sp., and Penicillium sp. Escherichia coli test results can be seen in Table 2.

Table 2

Escherichia coli test results on "Basa Genep" seasoning samples which is in the Traditional market of East Denpasar District

\begin{tabular}{|c|c|c|c|c|}
\hline No & Market Name & Sample Code & $\begin{array}{c}\text { Test result } \\
\text { (Colonies / gram) }\end{array}$ & Information \\
\hline 1. & Yadnya Market & PS1 & $<3.6 / g$ & MS \\
\hline 2. & Yadnya Market & PS2 & $<3.6 / \mathrm{g}$ & MS \\
\hline 3. & Yadnya Market & PS3 & $<3.6 / \mathrm{g}$ & MS \\
\hline 4. & Yadnya Market & PS4 & $<3.6 / \mathrm{g}$ & MS \\
\hline 5. & Yadnya Market & PS5 & $<3.6 / \mathrm{g}$ & MS \\
\hline 6. & Yadnya Market & PS6 & $<3.6 / \mathrm{g}$ & MS \\
\hline 7. & Yadnya Market & PS7 & $<3.6 / \mathrm{g}$ & MS \\
\hline 8. & Tamba Market & PS8 & $<3.6 / \mathrm{g}$ & MS \\
\hline 9. & Tamba Market & PS9 & $<3.6 / \mathrm{g}$ & MS \\
\hline 10. & Tamba Market & PS10 & $<3.6 / \mathrm{g}$ & MS \\
\hline 11. & Tamba Market & PS11 & $<3.6 / \mathrm{g}$ & MS \\
\hline 12. & Tamba Market & PS12 & $<3.6 / \mathrm{g}$ & MS \\
\hline 13. & Gunung Sari Market & PS13 & $<3.6 / \mathrm{g}$ & MS \\
\hline 14. & Gunung Sari Market & PS14 & $<3.6 / \mathrm{g}$ & MS \\
\hline 15. & Gunung Sari Market & PS15 & $<3.6 / \mathrm{g}$ & MS \\
\hline 16. & Gunung Sari Market & PS16 & $<3.6 / \mathrm{g}$ & MS \\
\hline 17. & Gunung Sari Market & PS17 & $<3.6 / \mathrm{g}$ & MS \\
\hline 18. & Gunung Sari Market & PS18 & $<3.6 / \mathrm{g}$ & MS \\
\hline 19. & Gunung Sari Market & PS19 & $<3.6 / \mathrm{g}$ & MS \\
\hline 20. & Kerta Sari Market & PS20 & $<3.6 / \mathrm{g}$ & MS \\
\hline 21. & Kerta Sari Market & $\mathrm{PS} 21$ & $<3.6 / \mathrm{g}$ & MS \\
\hline 22. & Kerta Sari Market & $\mathrm{PS} 22$ & $<3.6 / \mathrm{g}$ & MS \\
\hline 23 & Kerta Sari Market & $\mathrm{PS} 23$ & $<3.6 / \mathrm{g}$ & MS \\
\hline 24. & Kerta Sari Market & $\mathrm{PS} 24$ & $<3.6 / \mathrm{g}$ & MS \\
\hline 25. & Kerta Sari Market & PS25 & $<3.6 / \mathrm{g}$ & MS \\
\hline 26. & Kerta Sari Market & PS26 & $<3.6 / \mathrm{g}$ & MS \\
\hline 27. & Kerta Sari Market & PS27 & $<3.6 / \mathrm{g}$ & MS \\
\hline 28. & Kerta Sari Market & $\mathrm{PS} 28$ & $<3.6 / \mathrm{g}$ & MS \\
\hline 29. & Waringin Sari Market & PS29 & $<3.6 / \mathrm{g}$ & MS \\
\hline 30. & Waringin Sari Market & PS30 & $<3.6 / \mathrm{g}$ & MS \\
\hline 31. & Waringin Sari Market & PS31 & $<3.6 / \mathrm{g}$ & MS \\
\hline 32. & Waringin Sari Market & PS32 & $<3.6 / \mathrm{g}$ & MS \\
\hline 33. & Pakraman trainer market & PS33 & $<3.6 / \mathrm{g}$ & MS \\
\hline 34. & Pakraman trainer market & PS34 & $<3.6 / \mathrm{g}$ & MS \\
\hline 35. & Pakraman Penatih market & PS35 & $<3.6 / \mathrm{g}$ & MS \\
\hline 36. & Pakraman Penatih market & PS36 & $<3.6 / \mathrm{g}$ & MS \\
\hline 37. & Pakraman Penatih market & PS37 & $<3.6 / \mathrm{g}$ & MS \\
\hline 38. & Pakraman Penatih market & PS38 & $<3.6 / \mathrm{g}$ & MS \\
\hline 39. & Pakraman Penatih market & PS39 & $<3.6 / \mathrm{g}$ & MS \\
\hline 40. & Tanjung Bungkak Market & PS40 & $<3.6 / \mathrm{g}$ & MS \\
\hline 41. & Tanjung Bungkak Market & PS41 & $<3.6 / \mathrm{g}$ & MS \\
\hline 42. & Tanjung Bungkak Market & PS42 & $<3.6 / \mathrm{g}$ & MS \\
\hline 43. & Tanjung Bungkak Market & PS43 & $<3.6 / \mathrm{g}$ & MS \\
\hline 44. & Tanjung Bungkak Market & PS44 & $<3.6 / \mathrm{g}$ & MS \\
\hline
\end{tabular}

MS: Qualify 


\subsection{Functions}

The results of mold testing on 44 samples of "Basa Genep" instant seasoning obtained from 7 traditional markets in East Denpasar District all met the requirements of BPOM RI Regulation No: 16 of 2016, namely the maximum limit of mold contamination in $2 \times 10^{2}$ colonies/gram of wet instant seasoning. The results of the mold test can be seen in Table 3.

Table 3

Results of Testing the Water Content of the "Basa Genep" Instant Seasoning there is a traditional market in the East Denpasar sub-district.

\begin{tabular}{|c|c|c|c|c|}
\hline No & $\begin{array}{l}\text { Name } \\
\text { Market }\end{array}$ & $\begin{array}{c}\text { Codes } \\
\text { Sample }\end{array}$ & $\begin{array}{c}\text { Result } \\
\text { Testing }\end{array}$ & Information \\
\hline 1. & Yadnya Market & PS1 & NSG & MS \\
\hline 2. & Yadnya Market & PS2 & NSG & MS \\
\hline 3. & Yadnya Market & PS3 & NSG & MS \\
\hline 4. & Yadnya Market & PS4 & NSG & MS \\
\hline 5. & Yadnya Market & PS5 & NSG & MS \\
\hline 6. & Yadnya Market & PS6 & NSG & MS \\
\hline 7. & Yadnya Market & PS7 & NGS & MS \\
\hline 8. & Tamba Market & PS8 & NSG & MS \\
\hline 9. & Tamba Market & PS9 & NSG & MS \\
\hline 10. & Tamba Market & PS10 & NSG & MS \\
\hline 11. & Tamba Market & PS11 & NGS & MS \\
\hline 12. & Tamba Market & PS12 & NGS & MS \\
\hline 13. & Gunung Sari Market & PS13 & NGS & MS \\
\hline 14. & Gunung Sari Market & PS14 & NGS & MS \\
\hline 15. & Gunung Sari Market & PS15 & NGS & MS \\
\hline 16. & Gunung Sari Market & PS16 & NGS & MS \\
\hline 17. & Gunung Sari Market & PS17 & NGS & MS \\
\hline 18. & Gunung Sari Market & PS18 & NGS & MS \\
\hline 19. & Gunung Sari Market & PS19 & NGS & MS \\
\hline 20. & Kerta Sari Market & PS20 & NGS & MS \\
\hline 21. & Kerta Sari Market & PS21 & NGS & MS \\
\hline 22. & Kerta Sari Market & PS22 & NGS & MS \\
\hline 23. & Kerta Sari Market & PS23 & NGS & MS \\
\hline 24. & Kerta Sari Market & PS24 & NGS & MS \\
\hline 25. & Kerta Sari Market & PS25 & NGS & MS \\
\hline 26. & Kerta Sari Market & PS26 & NGS & MS \\
\hline 27. & Kerta Sari Market & PS27 & NGS & MS \\
\hline 28. & Kerta Sari Market & PS28 & NGS & MS \\
\hline 29. & Waringin Sari Market & PS29 & NGS & MS \\
\hline 30. & Waringin Sari Market & PS30 & NGS & MS \\
\hline 31. & Waringin Sari Market & PS31 & NGS & MS \\
\hline 32. & Waringin Sari Market & PS32 & NGS & MS \\
\hline 33. & Pakraman Trainer Market & PS33 & NGS & MS \\
\hline 34. & Pakraman Trainer Market & PS34 & NGS & MS \\
\hline 35. & Pakraman Penatih Market & PS35 & NGS & MS \\
\hline 36. & Pakraman Penatih Market & PS36 & NGS & MS \\
\hline 37. & Pakraman Penatih Market & PS37 & NGS & MS \\
\hline 38. & Pakraman Penatih Market & PS38 & NGS & MS \\
\hline 39. & Pakraman Penatih Market & PS39 & NGS & MS \\
\hline 40. & Tanjung Bungkak Market & PS40 & NGS & MS \\
\hline 41. & Tanjung Bungkak Market & PS41 & NGS & MS \\
\hline 42. & Tanjung Bungkak Market & PS42 & NGS & MS \\
\hline 43. & Tanjung Bungkak Market & PS43 & NGS & MS \\
\hline 44. & Tanjung Bungkak Market & PS44 & NGS & MS \\
\hline
\end{tabular}

NGS: (Non-Specific Growth)

According to [4] growth was not found in instant spices because it was caused by one of the raw materials for the instant seasoning itself, namely garlic. The ability of garlic tubers to inhibit microbial growth is very broad, including viruses, bacteria, protozoa, and fungi. Judging from the optimum temperature for mold growth, which is around $25-30^{\circ} \mathrm{C}$, mold is a microbe that is most likely to damage instant seasoning products during storage. Likewise in terms of the results of the 
$\mathrm{pH}$ test which tends to be acidic. Some molds can grow in a wide $\mathrm{pH}$ range of $2.0-8.5$. However, based on the observations, there was no found any mold growth in the "Basa Genep" Instant Seasoning product [5]. This is because the storage time for instant spices ranges from 2-3 days.

\subsection{Moisture Content The water}

The content of the seasoning was $21.62 \%-23.70 \%$. This figure shows the amount of water contained in Basa Genep instant seasoning found in the traditional market, East Denpasar subdistrict. Water content test results can be seen in Table 4 and Figure 1.

Table 4

Results of Testing the Water Content of the "Basa Genep" Instant Seasoning there is a traditional market in the East Denpasar sub-district.

\begin{tabular}{|c|c|c|c|c|}
\hline No. & Market Name & $\begin{array}{c}\text { Code } \\
\text { Sample } \\
\end{array}$ & $\begin{array}{c}\text { Score } \\
\text { Kadar Air }\end{array}$ & Information \\
\hline 1. & Yadnya Market & PS1 & 23.70 & TMS \\
\hline 2. & Yadnya Market & PS2 & 22.75 & TMS \\
\hline 3. & Yadnya Market & PS3 & 22.67 & TMS \\
\hline 4. & Yadnya Market & PS4 & 21.56 & TMS \\
\hline 5. & Yadnya Market & PS5 & 22.85 & TMS \\
\hline 6. & Yadnya Market & PS6 & 21.89 & TMS \\
\hline 7. & Yadnya Market & PS7 & 22.31 & TMS \\
\hline 8. & Tamba Market & PS8 & 21.62 & TMS \\
\hline 9. & Tamba Market & PS9 & 22.47 & TMS \\
\hline 10. & Tamba Market & PS10 & 23.18 & TMS \\
\hline 11. & Tamba Market & PS11 & 22.37 & TMS \\
\hline 12. & Tamba Market & PS12 & 22.64 & TMS \\
\hline 13. & Gunung Sari Market & PS13 & 22.40 & TMS \\
\hline 14. & Gunung Sari Market & PS14 & 22.84 & TMS \\
\hline 15. & Gunung Sari Market & PS15 & 21.95 & TMS \\
\hline 16. & Gunung Sari Market & PS16 & 22.46 & TMS \\
\hline 17. & Gunung Sari Market & PS17 & 22.54 & TMS \\
\hline 18. & Gunung Sari Market & PS18 & 23.01 & TMS \\
\hline 19. & Gunung Sari Market & PS19 & 22.06 & TMS \\
\hline 20. & Kerta Sari Market & PS20 & 22.47 & TMS \\
\hline 21. & Kerta Sari Market & $\mathrm{PS} 21$ & 22.34 & TMS \\
\hline 23. & Kerta Sari Market & PS23 & 23.69 & TMS \\
\hline 24. & Kerta Sari Market & $\mathrm{PS} 24$ & 22.59 & TMS \\
\hline 25. & Kerta Sari Market & $\mathrm{PS} 25$ & 22.43 & TMS \\
\hline 26. & Kerta Sari Market & PS26 & 23.44 & TMS \\
\hline 27. & Kerta Sari Market & PS27 & 22.58 & TMS \\
\hline 28. & Kerta Sari Market & PS28 & 23.05 & TMS \\
\hline 29. & Waringin Sari Market & PS29 & 22.27 & TMS \\
\hline 30. & Waringin Sari Market & PS30 & 22.17 & TMS \\
\hline 31. & Waringin Sari Market & PS31 & 22.36 & TMS \\
\hline 32. & Waringin Sari Market & PS32 & 22.78 & TMS \\
\hline 33. & Pakraman Penatih Market & PS33 & 22.04 & TMS \\
\hline 34. & Pakraman Penatih Market & PS34 & 22.05 & TMS \\
\hline 35. & Pakraman Penatih Market & PS35 & 22.25 & TMS \\
\hline 36. & Pakraman Penatih Market & PS36 & 23.20 & TMS \\
\hline 37. & Pakraman Penatih Market & PS37 & 21.86 & TMS \\
\hline 38 & Pakraman Penatih Market & PS38 & 22.30 & TMS \\
\hline 39. & Pakraman Penatih Market & PS39 & 22.15 & TMS \\
\hline 40. & Tanjung Bungkak Market & PS40 & 22.54 & TMS \\
\hline 41. & Tanjung Bungkak Market & PS41 & 22.36 & TMS \\
\hline 42. & Tanjung Bungkak Market & PS42 & 22.92 & TMS \\
\hline 43. & Tanjung Bungkak Market & PS43 & 23.40 & TMS \\
\hline 44. & Tanjung Bungkak Market & PS44 & 22.86 & TMS \\
\hline
\end{tabular}

TMS: Not eligible 
According to [6] spices can also increase the water content of spices. This is due to the nature of the spices that can draw moisture from the surrounding environment during the spice storage process. The higher the moisture content in a product, the faster the product will break down. Bacterial growth is faster in products with high water content [7].

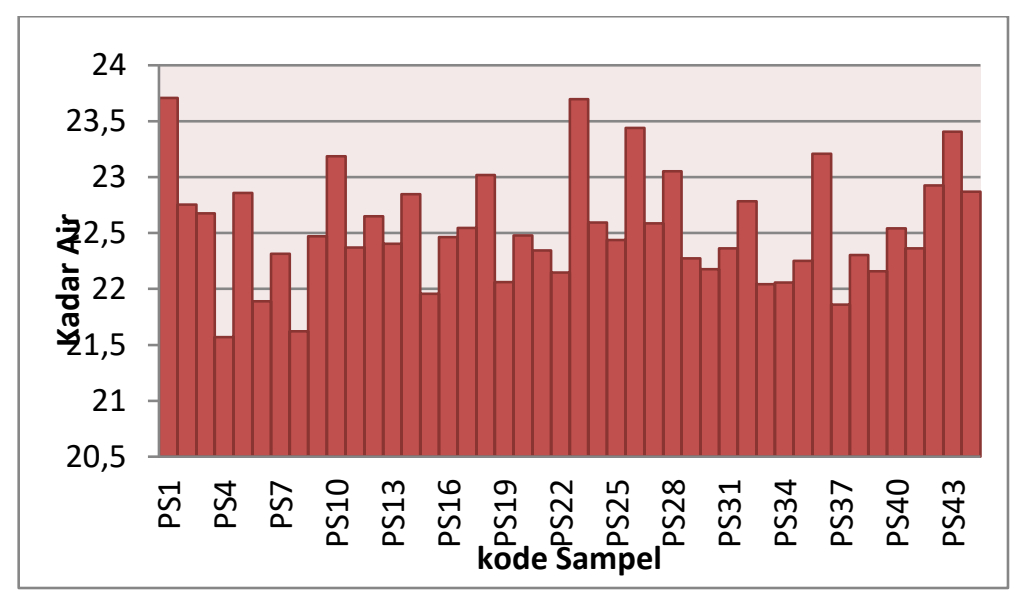

Figure 1

Results of Water Content Testing for Instant Seasoning "Basa Genep" which is located in the traditional market, East Denpasar sub-district.

\subsection{Degree of Acidity (pH)}

The results of $\mathrm{pH}$ testing on 44 samples of Basa Genep instant seasoning obtained from 7 traditional markets in East Denpasar sub-district have a $\mathrm{pH}$ value ranging from 2.2-5.25, all samples meet the BPOM RI No: 16 the year 2016 requirements, namely the maximum $\mathrm{pH}$ value limit at the wet instant seasoning is 5-6. The storage time for the wet instant spices has a significant effect on the $\mathrm{pH}$ value of the "Basa Genep" instant spices. The $\mathrm{pH}$ of the Basa Genep instant spices ranges from 2.2 to 5.25. At low $\mathrm{pH}$, the growth of some bacteria will die so that it can extend the shelflife.

In addition to the shelf life of the antimicrobial activity of traditional industrial cooking spices against pathogenic and destructive bacteria, it is stated that if the $\mathrm{pH}$ value is low enough around 4.0 - 6.0 then bacteria generally cannot reproduce properly in wet instant seasonings. It is suspected that the components of spices, such as red chilies and turmeric, can cause the low $\mathrm{pH}$ value of the spices [8]. The results of the acidity degree $(\mathrm{pH})$ test can be seen in Table 5 and Figure 2.

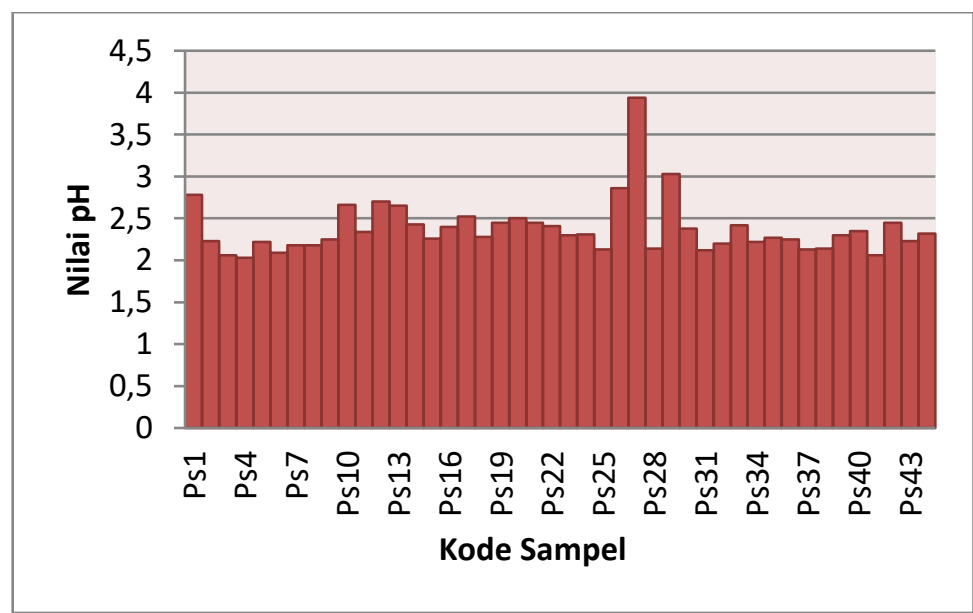

Figure 2.

The test results on the $\mathrm{pH}$ value of the "Basa Genep" instant spices there is a traditional market in the East Denpasar sub-district 
Table 5

The test results on the $\mathrm{pH}$ value of "Base Genep" instant seasoning there is a traditional market in the East Denpasar sub-district.

\begin{tabular}{|c|c|c|c|c|}
\hline No & Market Name & $\begin{array}{c}\text { Code } \\
\text { sample }\end{array}$ & pH value & Information \\
\hline 1. & Yadnya Market & PS1 & 2.78 & MS \\
\hline 2. & Yadnya Market & PS2 & 2.23 & MS \\
\hline 3. & Yadnya Market & PS3 & 2.06 & MS \\
\hline 4. & Yadnya Market & PS4 & 2.03 & MS \\
\hline 5. & Yadnya Market & PS5 & 2.22 & MS \\
\hline 6. & Yadnya Market & PS6 & 2.09 & MS \\
\hline 7. & Yadnya Market & PS7 & 2.18 & MS \\
\hline 8. & Tamba Market & PS8 & 2.18 & MS \\
\hline 9. & Tamba Market & PS9 & 2.25 & MS \\
\hline 10. & Tamba Market & PS10 & 2.66 & MS \\
\hline 11. & Tamba Market & PS11 & 2.34 & MS \\
\hline 12. & Tamba Market & PS12 & 2.70 & MS \\
\hline 13. & Gunung Sari Market & PS13 & 2.65 & MS \\
\hline 14. & Gunung Sari Market & PS14 & 2.43 & MS \\
\hline 15. & Gunung Sari Market & PS15 & 2.26 & MS \\
\hline 16. & Gunung Sari Market & PS16 & 2.40 & MS \\
\hline 17. & Gunung Sari Market & PS17 & 2.52 & MS \\
\hline 18. & Gunung Sari Market & PS18 & 2.28 & MS \\
\hline 19. & Gunung Sari Market & PS19 & 2.45 & MS \\
\hline 20. & Kerta Sari Market & PS20 & 2.50 & MS \\
\hline 21. & Kerta Sari Market & $\mathrm{P} 21$ & 2.45 & MS \\
\hline 22. & Kerta Sari Market & PS22 & 2.41 & MS \\
\hline 23. & Kerta Sari Market & PS23 & 2.30 & MS \\
\hline 24. & Kerta Sari Market & PS24 & 2.31 & MS \\
\hline 25 . & Kerta Sari Market & PS25 & 2.13 & MS \\
\hline 26. & Pasar Kerta Sari & PS26 & 2.86 & MS \\
\hline 27. & Kerta Sari Market & PS27 & 3.94 & MS \\
\hline 28. & Kerta Sari Market & PS28 & 2.14 & MS \\
\hline 29. & Waringin Sari Market & PS29 & 3.03 & MS \\
\hline 30. & Waringin Sari Market & PS30 & 2.38 & MS \\
\hline 31. & Waringin Sari Market & PS31 & 2.12 & MS \\
\hline 32. & Waringin Sari Market & PS32 & 2.20 & MS \\
\hline 33. & Pakraman Penatih Market & PS33 & 2.42 & MS \\
\hline 34. & Pakraman Penatih Market & PS34 & 2.22 & MS \\
\hline 35. & Penatih Pakraman market & PS35 & 2.27 & MS \\
\hline 36. & Penatih Pakraman market & PS36 & 2.25 & MS \\
\hline 37. & Penatih Pakraman market & PS37 & 2.13 & MS \\
\hline 38. & Penatih Pakraman market & PS38 & 2.14 & MS \\
\hline 39. & Penatih Pakraman market & PS39 & 2.30 & MS \\
\hline 40. & Tanjung Bungkak Market & PS40 & 2.35 & MS \\
\hline 41. & Tanjung Bungkak Market & PS41 & 2.06 & MS \\
\hline 42. & Tanjung Bungkak Market & PS42 & 2.45 & MS \\
\hline 43. & Tanjung Bungkak Market & PS43 & 2.23 & MS \\
\hline 44. & Tanjung Bungkak Market & PS44 & 2.32 & MS \\
\hline
\end{tabular}

MS: Qualified 


\section{Conclusion}

Based on the laboratory test results on 44 samples of instant seasoning "Base Genep", the results of the Total Plate Count (TPC) test on 44 samples of instant seasoning "Base Genep" all meet the requirements of BPOM RI Regulation No: 16 of 2016, namely the maximum limit of Total Plate Count (TPC) on instant base seasoning 1x104 Colonies/gram, Eschericia coli test results on 44 samples of "Base Genep" instant spices all meet the requirements of BPOM RI Regulation No: 16 of 2016, namely the maximum limit of Eschericia coli contamination in wet instant seasonings <3.6 I gram, the results of the mold test on 44 samples of instant seasoning "Base Genep" all meet the requirements of BPOM RI Regulation No: 16 of 2016, namely the maximum limit of mold contamination $2 \times 104$ colony / g. The water content of the spices was $21.62 \%-23.707 \%$, the pH value ranged from 2.2-3.94, all samples fulfilled the BPOM RI No: 16/2016, namely the maximum $\mathrm{pH}$ value of the 5-6 alkaline ingredients.

\section{References}

[1] Rahayu, WP (2000). Antimicrobial activity of traditional industrial cooking spices against pathogenic and destructive bacteria. Bul Teknol and Food Industry, 2 (11): 42-48.

[2] Yuharmen, Y. Eryanti, and Nurbalatif. (2002). Antimicrobial activity test of essential oils and methanol extract of galangal (Alpinia galanga) Chemistry Department. Riau University.

[3] Yuliati (2016). Test the effectiveness of turmeric extract as an antibacterial in the growth of Bacillus sp. And Shigella dysentriae in vitro (Uji efektivitas ekstrak kunyit sebagai antibakteri dalam pertumbuhan bakteri Bacillus sp. dan Shigella dysentriae secara in vitro). Jurnal Profesi Medika. 10(1):26-32.

[4] Hernawan, U. E and Setyawan, AD. (2003). review: Garlic Organosulfur Compounds (Allium sativum L.) and Their Biological Activities. Journal of Biopharmaceuticals. 1 (2): 65-76

[5] Mujianto. B. Angki P. Siti. R. (2013). Identification of Preservatives and Hazardous Coloring in Milled Seasoning. Journal of health science \& technology volume I Jakarta.

[6] Thalib, A. (2011). Effect of Type of Packaging on Shelf Life of Pasta Curry Seasoning. Journal of Industrial Research Results.

[7] Julianingsih and Prasetyo F. (2003). Determination of Processing and Serving Conditions for Instant Rawon Powder with the Taguchi Method. Journal of Industrial Engineering. 5 (2): pp. 1-19.

[8] Thalib, A. (2011). The Effect of Packaging Type on Shelf Life of Pasta Curry Seasoning Journal of Industrial Research Results. 